
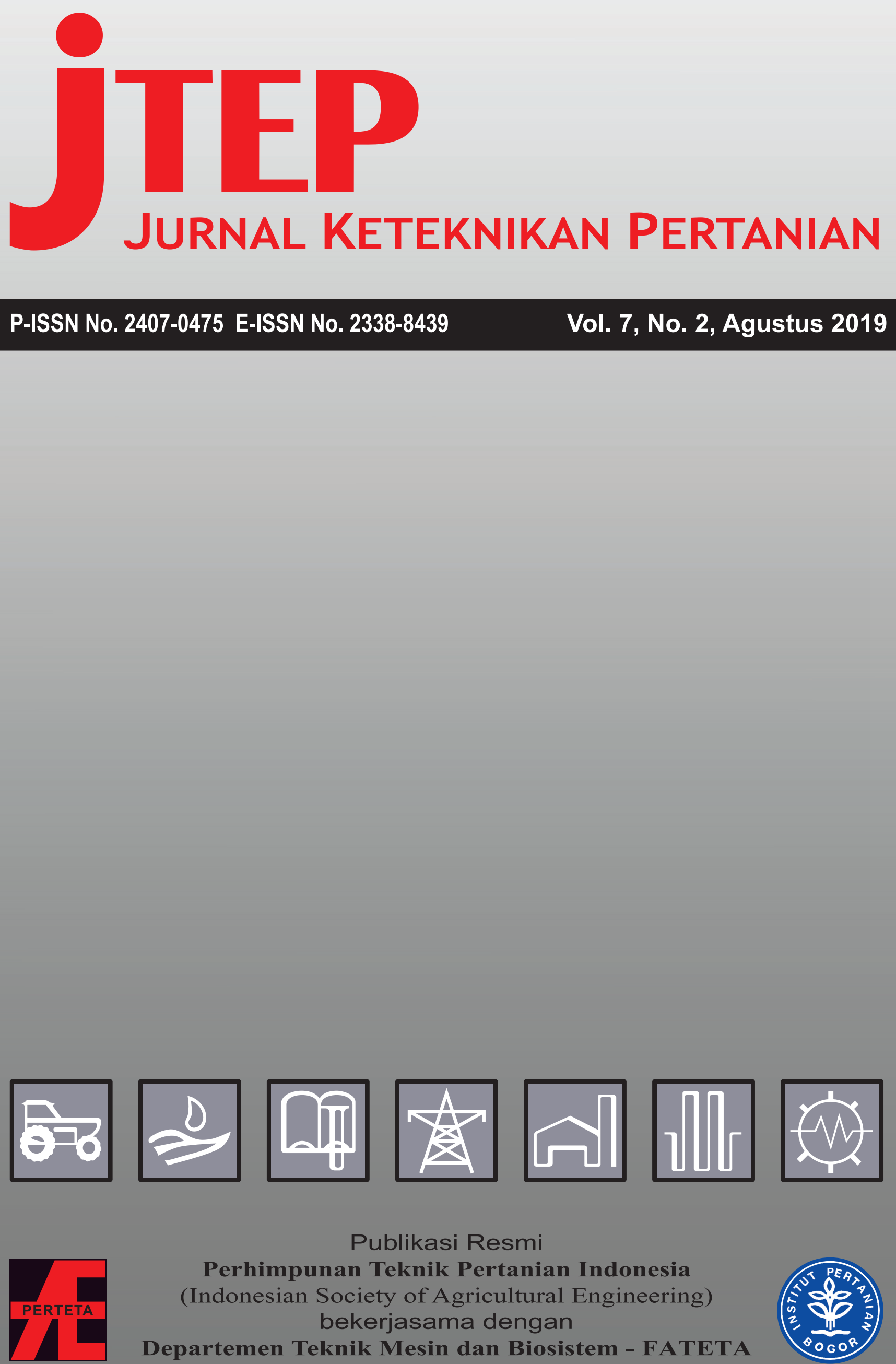

\footnotetext{
Publikasi Resmi

Perhimpunan Teknik Pertanian Indonesia (Indonesian Society of Agricultural Engineering) bekerjasama dengan

Departemen Teknik Mesin dan Biosistem - FATETA Institut Pertanian Bogor
}

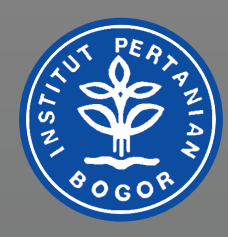




\section{jteP JURNAL Keteknikan PERTANIAN}

Jurnal Keteknikan Pertanian (JTEP) terakreditasi berdasarkan SK Dirjen Penguatan Riset dan Pengembangan Kementerian Ristek Dikti Nomor l/E/KPT/2015 tanggal 21 September 2015. Selain itu, JTEP juga telah terdaftar pada Crossref dan telah memiliki Digital Object Identifier (DOI) dan telah terindeks pada ISJD, IPI, Google Scholar dan DOAJ. JTEP terbit tiga kali setahun yaitu bulan April, Agustus dan Desember, Jurnal berkala ilmiah ini berkiprah dalam pengembangan ilmu keteknikan untuk pertanian tropika dan lingkungan hayati. Penulis makalah tidak dibatasi pada anggota PERTETA tetapi terbuka bagi masyarakat umum. Lingkup makalah, antara lain meliputi teknik sumberdaya lahan dan air, alat dan mesin budidaya pertanian, lingkungan dan bangunan pertanian, energi alternatif dan elektrifikasi, ergonomika dan elektronika pertanian, teknik pengolahan pangan dan hasil pertanian, manajemen dan sistem informasi pertanian. Makalah dikelompokkan dalam invited paper yang menyajikan isu aktual nasional dan internasional, review perkembangan penelitian, atau penerapan ilmu dan teknologi, technical paper hasil penelitian, penerapan, atau diseminasi, serta research methodology berkaitan pengembangan modul, metode, prosedur, program aplikasi, dan lain sebagainya. Penulisan naskah harus mengikuti panduan penulisan seperti tercantum pada website dan naskah dikirim secara elektronik (online submission) melalui http://journal.ipb.ac.id/index.php/jtep.

\section{Penanggungjawab:}

Ketua Departemen Teknik Mesin dan Biosistem, Fakultas Teknologi Pertanian,IPB

Ketua Perhimpunan Teknik Pertanian Indonesia

\section{Dewan Redaksi:}

Ketua : Yohanes Aris Purwanto (Scopus ID: 6506369700, IPB University)

Anggota : Abdul Hamid Adom (Scopus ID: 6506600412, University Malaysia Perlis)

(editorial Addy Wahyudie (Scopus ID: 35306119500, United Arab Emirates University)

board) Budi Indra Setiawan (Scopus ID: 55574122266, IPB University)

Balasuriya M.S. Jinendra (Scopus ID: 30467710700 , University of Ruhuna)

Bambang Purwantana (Scopus ID: 6506901423, Universitas Gadjah Mada)

Bambang Susilo (Scopus ID: 54418036400, Universitas Brawijaya)

Daniel Saputera (Scopus ID: 6507392012, Universitas Sriwjaya)

Han Shuqing (Scopus ID: 55039915600, China Agricultural University)

Hiroshi Shimizu (Scopus ID: 7404366016, Kyoto University)

I Made Anom Sutrisna Wijaya (Scopus ID: 56530783200, Universitas Udayana)

Agus Arif Munawar (Scopus ID: 56515099300, Universitas Syahkuala)

Armansyah H. Tambunan (Scopus ID: 57196349366, IPB University)

Kudang Boro Seminar (Scopus ID: 54897890200, IPB University)

M. Rahman (Scopus ID: 7404134933, Bangladesh Agricultural University)

Machmud Achmad (Scopus ID: 57191342583, Universitas Hasanuddin)

Muhammad Makky (Scopus ID: 55630259900, Universitas Andalas)

Muhammad Yulianto (Scopus ID: 54407688300, IPB University \& Waseda University)

Nanik Purwanti (Scopus ID: 23101232200, IPB University \& Teagasc Food Research Center Irlandia)

Pastor P. Garcia (Scopus ID: 57188872339 , Visayas State University)

Rosnah Shamsudin (Scopus ID: 6507783529, Universitas Putra Malaysia)

Salengke (Scopus ID: 6507093353, Universitas Hasanuddin)

Sate Sampattagul (Scopus ID: 7801640861, Chiang Mai University)

Subramaniam Sathivel (Scopus ID: 6602242315, Louisiana State University)

Shinichiro Kuroki (Scopus ID: 57052393500, Kobe University)

Siswoyo Soekarno (Scopus ID: 57200222075 , Universitas Jember)

Tetsuya Araki (Scopus ID: 55628028600, The University of Tokyo)

Tusan Park (Scopus ID: 57202780408, Kyungpook National University) 


\section{Redaksi Pelaksana:}

Ketua : Usman Ahmad (Scopus ID: 55947981500, IPB University)

Sekretaris : Lenny Saulia (Scopus ID: 16744818700, IPB University)

Bendahara : Dyah Wulandani (Scopus ID: 1883926600, IPB University)

Anggota : Satyanto Krido Saptomo (Scopus ID: 6507219391, IPB University)

Slamet Widodo (Scopus ID: 22636442900, IPB University)

Liyantono (Scopus ID: 54906200300, IPB University)

Leopold Oscar Nelwan (Scopus ID: 56088768900, IPB University)

I Wayan Astika (Scopus ID: 43461110500, IPB University)

Agus Ghautsun Niam (Scopus ID: 57205687481, IPB University)

Administrasi : Diana Nursolehat (IPB University)

Penerbit: Perhimpunan Teknik Pertanian Indonesia (PERTETA) bekerjasama dengan Departemen Teknik Mesin dan Biosistem, Institut Pertanian Bogor.

Alamat: Jurnal Keteknikan Pertanian, Departemen Teknik Mesin dan Biosistem, Fakultas Teknologi Pertanian, Kampus Institut Pertanian Bogor, Bogor 16680.

Telp. 0251-8624 503, Fax 0251-8623 026,

E-mail: jtep@ipb.ac.id atau jurnaltep@yahoo.com

Website: web.ipb.ac.id/ jtep atau http://journal.ipb.ac.id/index.php/jtep

Rekening: BRI, KCP-IPB, No.0595-01-003461-50-9 a/n: Jurnal Keteknikan Pertanian

Percetakan: PT. Binakerta Makmur Saputra, Jakarta 


\section{Ucapan Terima Kasih}

Redaksi Jurnal Keteknikan Pertanian mengucapkan terima kasih kepada para Mitra Bebestari yang telah menelaah (me-review) Naskah pada penerbitan Vol. 7 No. 2 Agustus 2019. Ucapan terima kasih disampaikan kepada: Prof. Dr. Ir. Bambang Purwantana, M.Agr (Fakultas Teknologi Pertanian, Universitas Gadjah Mada), Bayu Dwi Apri Nugroho, PhD (Fakultas Teknologi Pertanian,Universitas Gadjah Mada), Ir. Darma, M.Si, Ph.D ( Fakultas Pertanian, Universitas Papua), Ir. Siti Mariana Widayanti, M.Si (Balai Besar Penelitian dan Pengembangan Pascapanen Pertanian), Prof.Dr.Ir. Tineke Mandang, (Departemen Teknik Mesin dan Biosistem, Fakultas Teknologi Pertanian, Institut Pertanian Bogor), Dr.Ir. I Wayan Budiastra, M.Agr (Departemen Teknik Mesin dan Biosistem, Fakultas Teknologi Pertanian, Institut Pertanian Bogor), Dr.Ir. Radite Praeko Agus Setiawan, M.Agr (Departemen Teknik Mesin dan Biosistem, Fakultas Teknologi Pertanian, Institut Pertanian Bogor), Dr.Ir. Leopold Oscar Nelwan, MSi (Departemen Teknik Mesin dan Biosistem, Fakultas Teknologi Pertanian, Institut Pertanian Bogor), Dr.Ir. Lenny Saulia, MSi (Departemen Teknik Mesin dan Biosistem, Fakultas Teknologi Pertanian, Institut Pertanian Bogor), Dr. Chusnul Arif, S.TP, MS (Departemen Teknik Sipil dan Lingkungan, Fakultas Teknologi Pertanian, Institut Pertanian Bogor) 


\title{
Desain dan Kinerja Mesin Ekstruder Twin Screw untuk Pembuatan Pakan Ikan Terapung
}

\section{Design and Performance of Twin Screw Extruders for Producing Floating Fish Feed}

Arif Rahman Hakim, Loka Riset Mekanisasi Pengolahan Hasil Perikanan,Badan Riset dan Sumberdaya Manusia, Kementerian Kelautan dan Perikanan. Email: arifrahmanh11@gmail.com

Wahyu Tri Handoyo, Loka Riset Mekanisasi Pengolahan Hasil Perikanan, Badan Riset dan Sumberdaya Manusia, Kementerian Kelautan dan Perikanan. Email: wahyu.th@gmail.com

Ahmat Fauzi, Loka Riset Mekanisasi Pengolahan Hasil Perikanan, Badan Riset dan Sumberdaya Manusia, Kementerian Kelautan dan Perikanan. Email: ahmat.fauzi@gmail.com

Widiarto Sarwono, Loka Riset Mekanisasi Pengolahan Hasil Perikanan, Badan Riset dan Sumberdaya Manusia, Kementerian Kelautan dan Perikanan. Email: widiarto06@gmail.com

\begin{abstract}
Production of floating fish feed independently by fish farmer group currently constrained with types of extruders available. Single screw extruders used fail to produce floating fish feed. It caused by the extrusion process is not optimal due to either temperature or improper screw speed. An alternative solution is using extruder twin screw with temperature and screw speed can be controlled. The objective of the study is developing and assessing of twin screw extruder performance in producing floating fish feed. Principle work of extruders is conveying and mixing feed stuff to the dies under high temperature and pressure. The main component of extruder consists of a motor drive, screw, barrel, heater, dies, and cutter. Evaluation of extruder performance involve temperature, screw speed, engine power, and quality of feed produced that are floatability and unit density. The result of design and assessment are obtained prototype of twin screw extruders which have capacity 10,93 kg/h, stability temperature and screw speed, the power requirement is $5,17 \mathrm{~kW}$, specific mechanical energy $136,11 \mathrm{~kJ}^{\mathrm{kg}}{ }^{-1}$. Produced fish feed have floatability $96 \%$ and unit density $0,620\left(\mathrm{~g} / \mathrm{cm}^{3}\right)$.
\end{abstract}

Keywords: Fish feed, floating, extruder, twin screw

\begin{abstract}
Abstrak
Pembuatan pakan ikan terapung secara mandiri oleh kelompok pembudidaya saat ini terkendala jenis ekstruder yang tersedia. Ekstruder single screw yang digunakan belum bisa menghasilkan pakan ikan terapung. Karena proses ekstrusi yang tidak optimal baik disebabkan suhu maupun putaran screw yang tidak tepat. Sebagai alternatif ialah dengan menggunakan ekstruder twin screw dengan suhu dan putaran yang bisa dikontrol. Tujuan penelitian ini adalah untuk mengembangkan dan menguji kinerja ekstruder twin screw dalam memproduksi pakan ikan terapung. Prinsip kerja dari ekstruder adalah mendorong dan mengaduk bahan pakan menuju dies dalam kondisi tekanan dan panas yang tinggi. Komponen utama ekstruder terdiri dari motor penggerak, twin screw, barrel, element pemanas, dies dan pemotong. Pengujian kinerja meliputi suhu, kecepatan screw, daya mesin serta kualitas pakan yang dihasilkan berupa daya apung dan unit density. Hasil desain dan pengujian diperoleh mesin ekstruder dengan kapasitas $10,93 \mathrm{~kg} / \mathrm{jam}$, suhu dan putaran screw stabil saat dioperasikan, kebutuhan daya sebesar 5,17 kW, specific

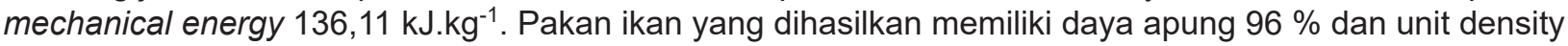
$0,620\left(\mathrm{~g} / \mathrm{cm}^{3}\right)$.
\end{abstract}

Kata Kunci: Pakan ikan, terapung, ekstruder, twin screw 


\section{Latar Belakang}

Harga pakan ikan terus mengalami kenaikan. Hal ini salah satunya disebabkan karena permintaan yang juga terus naik selain faktor kenaikan harga bahan baku (tepung ikan). Sebagai salah satu cara mengatasi dampak negatif dari kenaikan pakan bagi para pembudidaya ikan Pemerintah menggulirkan Program Gerakan Pakan Ikan Mandiri. Dengan program ini para pembudidaya ikan diharapkan mampu memproduksi pakan ikan secara mandiri sehingga bisa menekan biaya pengadaan pakan (DJPB, 2015).

Pakan ikan dibagi menjadi 2 jenis yaitu pakan ikan tenggelam dan pakan ikan terapung. Pakan jenis terapung memiliki keunggulan dibandingkan pakan ikan tenggelam diantaranya kecernaan lebih tinggi, mudah dikontrol jumlah pemberiannya dan tidak menyebabkan kualitas air kolam menurun (Kurniawan \& Lestariadi, 2017; Yaqoob, et al 2010; Gunadi dkk, 2010). Tetapi dalam proses pembuatannya pakan terapung lebih komplek dibandingkan pakan tenggelam. Penyebabnya ialah pakan terapung diperlukan proses ekstrusi yang tepat agar pakan bisa membentuk struktur pori sehingga bisa mengapung (Purwasasmita \& Roland, 2008).

Ekstruder sebagai mesin utama dalam proses ekstrusi harus didesain sedemikian rupa sehingga mampu menghasilkan pakan ikan terapung yang berkualitas. Oleh karenanya ekstruder harus bisa menyediakan kondisi suhu, tekanan dan pengadukan yang optimal. Mesin ekstruder yang banyak beredar dikelompok-kelompok budidaya ikan adalah ekstruder dengan ulir tunggal (single screw), yang sebagian besar sumber panasnya berasal dari gesekan antara bahan dan selongsong (barrel) dari ekstruder. Panas tersebut sulit dikontrol akibatnya bisa kurang panas maupun terlalu panas yang keduanya akan menghambat pembentukan pakan terapung dan bisa juga menyebabkan bahan tidak bisa dialirkan screw karena terlalu kering sehingga mesin akan macet. Sedangkan mesin ekstruder jenis ulir ganda (twin screw) memiliki beberapa kelebihan dibandingkan jenis single screw yaitu proses gesekan antara bahan dan barrel bisa dikurangi dan pengadukan lebih homogen (Adekola, 2016; Evon, et al. 2009; Harold et al. 2005).

Penelitian terkait aplikasi ekstruder twin screw dalam pengolahan pakan dan pangan sudah banyak dilakukan. Senanayake \& Clarke (1999) merancang mesin ekstruder twin screw untuk memproduksi snack

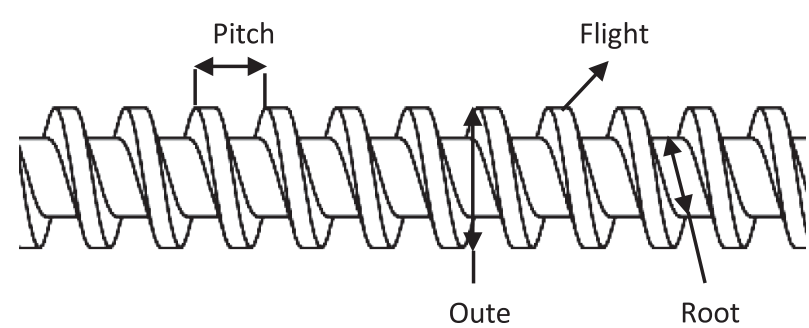

Gambar 1. Bagian-bagian screw. berbahan pisang dan beras. Philipp, et al, (2017) yang melakukan penelitian pembuatan snack berpotein tinggi menggunakan mesin twin screw ekstruder. Demikian juga Budijanto dkk (2012) mengaplikasikan mesin ekstruder twin screw untuk pembuatan sereal dari bekatul. Penelitian lain seperti Purwasasmita dan Roland (2008); Draganovica et al (2011); Samuelsen et al (2018), melakukan pengujian kualitas pakan ikan yang diproduksi menOggunakan mesin ekstruder twin screw, belum membahas performansi mesin yang digunakan.

Lebih lanjut, dari penelitian-penelitian tersebut belum ada yang spesifik mendesain dan mengkonstruksi ekstruder untuk produksi pakan terapung dan uji kinerjanya terhadap mutu pakan yang dihasilkan. Sehingga tujuan dari penelitian ini adalah membuat ekstruder twin screw dengan kapasitas $10 \mathrm{~kg} / \mathrm{jam}$ melalui perhitungan rancangan desain, konstruksi dan pengujian mesin yang digunakan untuk membuat pakan ikan terapung.

\section{Bahan dan Metode}

\section{Peralatan dan Bahan}

Peralatan yang digunakan adalah peralatanperalatan dalam konstruksi mesin ekstruder dan peralatan uji kinerja ekstruder yaitu timbangan analitik Fujitsu HTR 220, Thermometer Lutron TM-946 probe tipe K/J, tachometer digital SE-100 Sanwa, kaliper Sigmat-Vernier dan tang ampere Sanwa DCM2000DR.

Bahan yang digunakan pada penelitian ini terdiri dari bahan pembuatan mesin dan bahan untuk pengujian. Bahan pembuatan mesin terdiri dari besi kanal U ukuran $65 \times 40 \times 3 \mathrm{~mm}$, plat besi/baja karbon S45C ketebalan 10 dan $20 \mathrm{~mm}$, plat stainless steel 304 ketebalan 1 dan $1,5 \mathrm{~mm}$, stainless steel 304 ukuran lebar x tebal $205 \times 45 \mathrm{~mm}$, as stainless steel 304 diameter $\varnothing$ 1,5 inch $(38,1 \mathrm{~mm})$, plat Al-05 ukuran lebar dan tebal $70 \times 55$ dan $50 \times 15 \mathrm{~mm}$, motor listrik 2 phase $7,5 \mathrm{~kW}$, inverter $7,5 \mathrm{~kW}$, motor listrik dan speed reducer 18-280 rpm, sensor dan kontrol temperatur, elemen pemanas. Bahan penyusun pakan yang dibuat meliputi tepung ikan, tepung kedelai, tepung jagung dan tepung tapioka.

\section{Rancangan Fungsional}

Ekstruder dirancang untuk memproduksi pakan ikan terapung melalui proses ekstrusi. Ekstruder ditargetkan mencetak pakan dengan ukuran diameter 3-5 $\mathrm{mm}$ dan berat jenis pakan lebih kecil dari $1 \mathrm{~g} / \mathrm{cm}^{3}$. Fungsi dari setiap bagian mesin dapat dilihat pada Tabel 1.

\section{Rancangan Struktural Screw}

Bagian utama dari ekstruder ialah screw. Screw dibuat ganda (twin) yang berputar secara berlawanan (counter rotating). Screw harus mampu mendorong dan menekan bahan baku supaya membentuk padatan. 
Tabel 1. Rancangan fungsional.

\begin{tabular}{|c|c|c|}
\hline Fungsi utama & Sub Fungsi & Komponen \\
\hline \multirow{5}{*}{$\begin{array}{l}\text { Mencetak pakan } \\
\text { berdiameter 3-5 mm } \\
\text { dan berat jenis pakan } \\
\text { lebih kecil dari } \\
1 \mathrm{~g} / \mathrm{cm}^{3}\end{array}$} & $\begin{array}{l}\text { Memutar, mengalirkan, mengaduk dan menekan bahan } \\
\text { dari hopper menuju dies dalam selongsong /barrel }\end{array}$ & Screw \\
\hline & Menahan tekanan akibat gerakan screw dan bahan & Barrel \\
\hline & $\begin{array}{l}\text { Membentuk sifat fisik pakanmeliputi densitas, rasio } \\
\text { pengembangan, tekstur permukaan dan ukuran serta bentuk }\end{array}$ & Dies \\
\hline & Memutar screw & Sistem penggerak \\
\hline & Menaikkan dan mengatur suhu barrel & Pemanas dan sensor suhu \\
\hline
\end{tabular}

Oleh karena itu material screw harus kuat, tidak mudah terdeformasi dan patah. Material screw yang digunakan adalah as stainless steel 304 diameter $\varnothing$ 1,5 inch $(38,1 \mathrm{~mm})$. Kapasitas sebuah mesin ekstruder ditentukan oleh ukuran screw yang meliputi diameter outer dan root, pitch serta lebar flight (Gambar 1). Oleh karena penentuan target kapasitas ekstruder diawali dengan perhitungan dimensi screw.

Target kapasitas mesin ekstruder pada penelitian ini ialah 9-11 kg/jam. Perhitungan kapasitas screw dalam mengalirkan bahan menggunakan persamaan 1 dibawah ini:

$Q=B H(2 \pi-\alpha) D N p$

Keterangan simbol:

$N=$ kecepatan putar screw (rpm)

$\alpha=$ overlap angle of screw flights (derajat)

$H=$ tinggi flight $(\mathrm{mm})$

$Q=$ aliran massa $\left(\mathrm{mm}^{3} / \mathrm{min}\right)$

$B=$ lebar channel $(\mathrm{mm})$

$p=\operatorname{pitch}(\mathrm{mm})$

$D=$ diameter outher screw $(\mathrm{mm})$

Selanjutnya dibuat dimensi screw berdasarkan target kapasitas tersebut. Detail dimensi screw terlihat pada Gambar 2. sebagai berikut:

\section{Barrel}

Barrel adalah selongsong dari screw yang harus mampu menahan tekanan akibat gerakan screw dan bahan. Tekanan dalam barrel tidak diketahui secara pasti sehingga dibutuhkan nilai asumsi untuk menentukan ketebalan dan jenis bahan dari barrel. Nilai asumsi bisa berdasarkan literatur maupun dari mesin ekstruder komersial yang memiliki bahan yang sama. Menurut Harper (1979) tekanan pada barrel di mesin ekstruder komersial bisa mencapai $17 \mathrm{MPa}$ (2500 psi) tetapi juga bisa berbeda tergantung panjang screw dan bahan yang digunakan. Pada penelitian ini diasumsikan maksimal tekanan yang akan terjadi ialah $10 \mathrm{MPa}$.

Oleh karena itu bahan yang dipilih berupa baja balok SUS 304 dengan ketebalan 19-20 mm dari silider screw sedangkan ukuran panjang dan lebar barrel adalah $278 \mathrm{~mm}$ dan $200 \mathrm{~mm}$. Detail desain barre/ bisa dilihat pada gambar 3. Barrel didesain menjadi dua bagian yaitu bagian atas dan bawah yang dilengkapi dengan engsel supaya dapat dibuka dengan tujuan agar screw mudah dibersihkan.

\section{Dies}

Lubang keluaran atau disebut Dies berperan penting dalam membentuk sifat fisik pakan. Saat produk keluar dari dies, tekanan dan temperature akan turun dengan tiba-tiba sehingga menyebabkan produk cenderung mengembang. Dies dibuat dengan bentuk kerucut, hal ini berujuan agar bahan yang mengalir dari ujung screw bisa dengan lancar menuju lubang dies. Lubang dies memiliki diameter $3 \mathrm{~mm}$ dengan jumlah lubang sebanyak 8 buah.

\section{Sistem penggerak}

Mesin twin screw ekstruder dilengkapi motor sebagai penggerak. Sistem penggerak yang digunakan
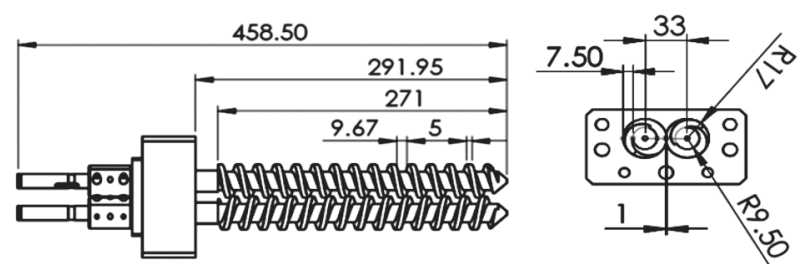

Gambar 2. Dimensi screw.
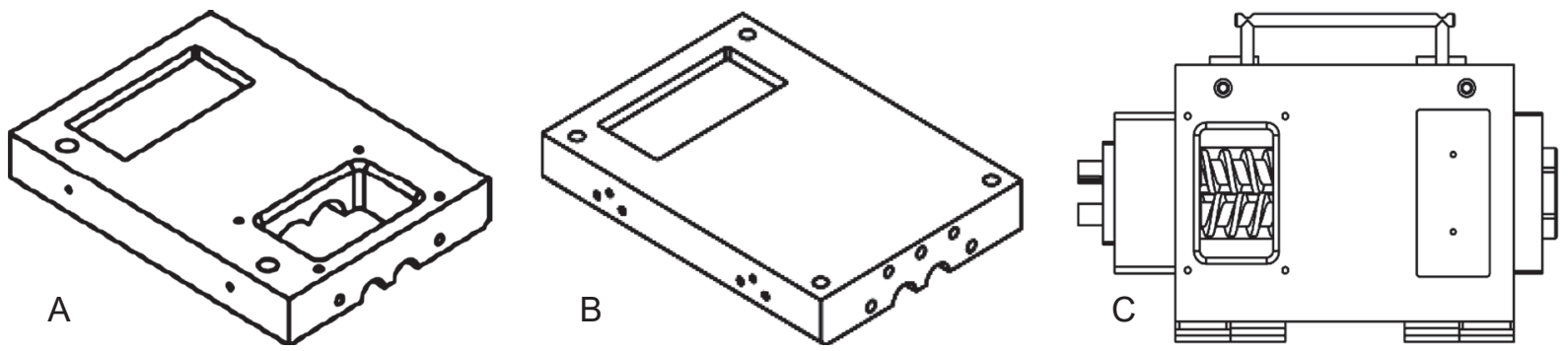

Gambar 3. Barrel atas (A), barrel bawah (B), barrel gabungan (C). 
berupa motor listrik 3 phase jenis induksi MA132MA 4 - 7.5 kW-50 Hz-1450 rpm dengan inverter WJ200 7.5 kW sebagai pengatur putaran. Untuk mentransmisikan daya motor penggerak ke twin screw digunakan coupling dan gear set yang menghubungkan antara as motor dengan as screw. Kebutuhan energi pada motor sebagai sistem penggerak sangat bervariasi tergantung dari bahan yang diolah serta kondisi proses yang diterapkan. Pada penelitian Senanake \& Clarke (1999), menyebutkan bahwa kebutuhan energi motor untuk kapasitas mesin ekstruder twin screw $10 \mathrm{~kg} /$ jam adalah $2.2 \mathrm{~kW}$. Sedangkan penelitian Muthukumarappan and Karunanithy (2000) menggunakan Persamaan 2. untuk menghitung kebutuhan energi. Hasil perhitungan menunjukkan bahwa kebutuhan daya mesin ekstruder sebesar 6.84 kW kemudian diperhitungkan faktor keselamatan dan ketersediaan motor sehingga diperoleh nilai $7.5 \mathrm{~kW}$.

$P=\tau \pi^{2} D^{2} N L$

\section{Dimana}

$$
\begin{aligned}
& P=\text { power }(\mathrm{W}) \\
& \tau=\text { shear stress }\left(\mathrm{N} . \mathrm{m}^{-2}\right) \\
& D=\text { diameter screw }(\mathrm{m}) \\
& N=\text { screw speed }(\mathrm{rpm}) \\
& L=\text { panjang screw }(\mathrm{m})
\end{aligned}
$$

\section{Pemanas dan sensor suhu}

Proses pembuatan pakan terapung dibutuhkan proses pemasakan yang optimal. Sehingga dibutuhkan alat yang mampu meningkatkan suhu barrel sesuai dengan kebutuhan. Alat tersebut ialah elemen pemanas listrik tipe plat (heater plate). Pemanas dipasang pada barrel atas dan barrel bawah dan diletakkan pada bagian ujung atau di bagian yang dekat dengan dies. Heater plate yang digunakan mampu menaikkan suhu hingga $200^{\circ} \mathrm{C}$.

Sensor suhu untuk zona pemanasan menggunakan jenis Thermo Couple : Standard Part $-200^{\circ} \mathrm{C} 2$ buah, letak thermocouple berada pada barre/ bagian atas dan bawah dengan jarak $10 \mathrm{~mm}$ dari screw. Selanjutnya untuk mengatur suhu ditambahkan kontrol temperatur jenis Autonics, TCN4M. Gambar keseluruhan mesin ekstruder tersaji pada gambar 4 sebagai berikut.

\section{Metode Pengujian dan Analisis Data Pengujian}

Pengujian mesin ekstruder meliputi pengukuran daya, suhu dan kestabilan putaran screw selama proses pembuatan pakan. Pengukuran daya menggunakan persamaan berikut :

Daya total $=1.73 \times$ Voltase $\times$ Arus $\times \cos \theta$

Jala-jala listrik atau voltase yang dipakai sebesar 220 volt dan arus diukur menggunakan Tang amper yang dicatat setiap menit dan nilai $\cos \theta$ motor sebesar 0.84 . Selanjutnya parameter suhu diukur menggunakan thermometer digital dengan thermocouple diletakkan didalam barre/ bagian atas dan bawah berjarak $10 \mathrm{~mm}$ dari screw. Berikutnya parameter kecepatan screw diukur menggunakan alat Tachometer digital, bagian atau titik yang diukur putarannya adalah putaran poros motor.

Beban yang digunakan ialah formula pakan yang terdiri dari tepung ikan (38\%), bungkil kedelai (22\%), tepung jagung $(22 \%)$ dan tepung tapioka (18\%) dengan berat total $5 \mathrm{~kg}$. Kemudian bahan tersebut ditambahkan air sebanyak 25\%. Kondisi ekstruder diatur pada suhu $100{ }^{\circ} \mathrm{C}$ dan kecepatan screw 600 rpm $(20 \mathrm{~Hz})$.

Pengoperasian ekstruder sebagai berikut: sistem kelistrikan ekstruder dinyalakan melalui kontrol panel, kemudian diatur suhu barrel atas dan bawah, setelah suhu tercapai putaran screw diatur sesuai kebutuhan. Formula pakan yang telah ditambahkan air dan homogen dimasukkan melalui hopper lalu diproses dalam screw dan dikeluarkan melalui dies yang berdiamater $3 \mathrm{~mm}$ berjumlah 8 buah. Pakan ikan yang keluar dari lubang dies dalam bentuk padatan langsung dipotong oleh pisau pemotong yang ditempatkan pada permukaan dies. Kecepatan putaran pisau pemotong dan kerapatan dengan permukaan dies berpengaruh terhadap panjang pendeknya ukuran pellet yang dihasilkan. Oleh karena itu kecepatan putaran pisau

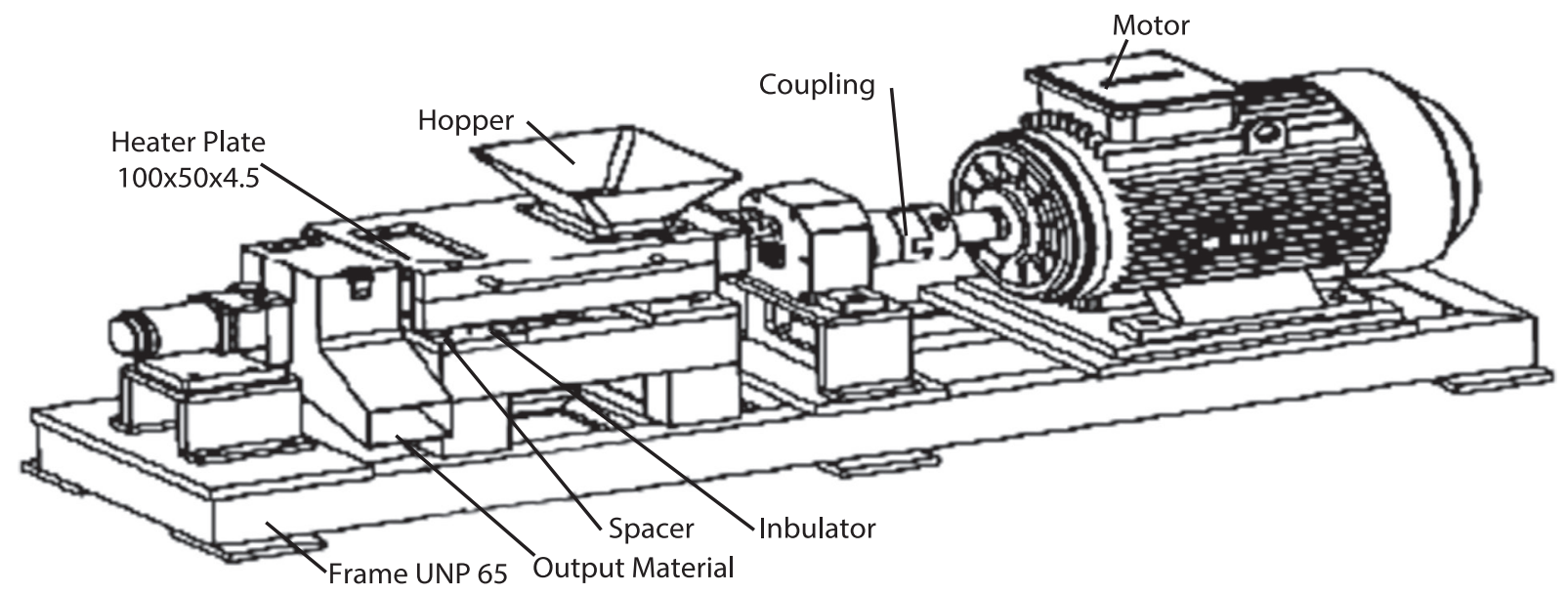

Gambar 4. Mesin ekstruder twin screw 
pemotong harus disesuaikan dengan kecepatan ekstrusi. Pisau pemotong digerakkan dengan motor DC yang dapat diatur kecepatannya sehingga bisa diperoleh pakan dengan ukuran tertentu. Pakan yang dihasilkan berbentuk bulat dengan diameter 3-4 mm.

Selanjutnya, untuk mengetahui performansi mesin dan kualitas pakan yang dihasilkan dilakukan uji dengan beberapa variasi suhu dan kecepatan putar screw. Mesin ekstruder diatur pada suhu barrel 80 , $90,100,110$ dan $120^{\circ} \mathrm{C}$ dan putaran screw 480,540 , 600 dan $660 \mathrm{rpm}$. Setelah suhu barrel tercapai sesuai perlakuan tersebut, formula dimasukkan ke ekstruder melalui hopper. Pakan yang dihasilkan selanjutnya dikeringkan. Masing-masing perlakuan diulang sebanyak 3 kali.

Parameter yang diamati meliputi unit density $(\mathrm{g} /$ $\left.\mathrm{cm}^{3}\right)$, daya apung $(\%)$, kapasitas mesin $(\mathrm{kg} / \mathrm{jam})$ dan specific mechanical energy/SME (kJ.kg $\left.{ }^{1}\right)$. Data yang diperoleh dianalisa menggunakan software Minitab 17. Persamaan untuk perhitungan parameter adalah sebagai berikut:

Unit density. Penentuan unit density berdasarkan Rosentrater et al (2009) sebagai berikut 10 butir pakan yang sudah kering masing-masing diukur panjang dan diameternya menggunakan penggaris kaliper lalu ditimbang beratnya menggunakan timbangan digital. Rata-rata berat massa pelet dibagi volume merupakan nilai dari unit density.

Unit density $=\frac{\text { berat pelet }(\mathrm{g})}{\text { volume pelet }\left(\mathrm{mm}^{3}\right)}$

Daya apung. 20 butir pelet dituang kedalam 1000 $\mathrm{ml}$ beaker glass berisi $800 \mathrm{ml}$ aquades pada suhu ruang. Jumlah pakan yang masih terapung (NF) selama 30 menit dibandingkan jumlah pelet awal (de Cruz et al, 2015). dengan persamaan sebagai berikut :

Daya apung $=\frac{N F}{20} \times 100$
Kapasitas mesin. $1 \mathrm{~kg}$ bahan pembuat pakan dimasukkan mesin ekstruder kemudian waktu dihitung hingga semua bahan masuk ekstruder. Kemudian semua pelet yang terbentuk ditimbang.

Kapasitas mesin $=\frac{\text { berat pelet yang terbentuk }(\mathrm{kg})}{\text { waktu yang dibutuhkan (jam) }}$

Spesific Mechanical Energy. SME adalah energi yang dikonsumsi oleh motor per satuan berat bahan. Dalam menghitung SME, harus dihitung dulu data kecepatan putar screw (n) dalam rpm, torsi motor (T) dan aliran massa bahan (MFR) dalam Kg/jam. Persamaan yang digunakan menurut Zhang et al. 2015 adalah sebagai berikut

$\operatorname{SME}\left(\frac{\mathrm{kJ}}{\mathrm{Kg}}\right)=\frac{2 \pi \times n \times T}{M F R}$

\section{Hasil dan Pembahasan}

\section{Konstruksi Ekstruder Hasil Rancangan}

Konstruksi ekstruder twin screw untuk pembuat pakan ikan terapung telah selesai dikerjakan (Gambar 5). Komponen utama ekstruder terdiri dari motor penggerak (1), coupling as motor dan screw (2), hopper (3), barrel screw elemen pemanas (4), dies (5), motor dan pisau pemotong (6) serta kontrol panel (6).

Prinsip kerja mesin ini ialah bahan baku pakan dialirkan melalui barrel screw dalam tekanan dan suhu tinggi lalu keluar melalui dies dan membentuk pellet dengan diameter 3-4 mm dan perpori. Kapasitas mesin adalah $10.93 \mathrm{~kg} / \mathrm{jam}$ Jenis screw berupa ulir ganda (twin) dengan gerakan counter rotating putaran bisa mencapai $700 \mathrm{rpm}$. Motor penggerak yang digunakan adalah motor AC $7.5 \mathrm{~kW}$. Pemanas yang diletakkan pada ujung barrel atas dan bawah mampu menaikkan suhu hingga $200^{\circ} \mathrm{C}$.

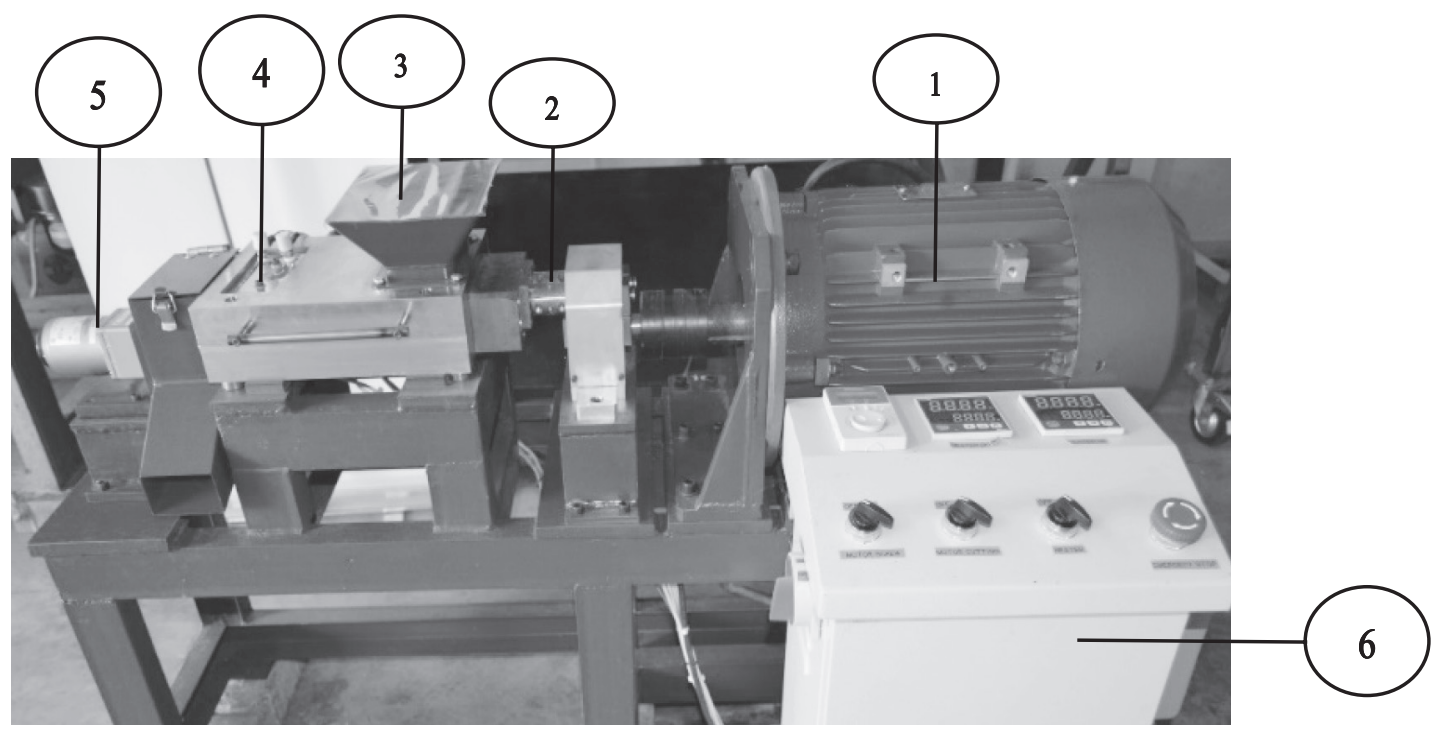

Gambar 5. Rancangbangun mesin ekstruder twin screw. 
Tabel 2. Performansi mesin ekstruder dan kualitas pakan

\begin{tabular}{lccclc}
\hline Perlakuan & & Kapasitas $(\mathrm{kg} / \mathrm{jam})$ & SME $\left(\mathrm{KJ} \mathrm{kg}^{-1}\right)$ & Daya Apung $(\%)$ & Unit Density $\left(\mathrm{g} / \mathrm{cm}^{3}\right)$ \\
\hline \multirow{3}{*}{ Putaran Screw } & 480 & $7.35 \pm 0.50 \mathrm{~b}$ & $234.14 \pm 5.52 \mathrm{a}$ & $30.00 \pm 5.00 \mathrm{c}$ & $0.782 \pm 0.03 \mathrm{a}$ \\
$(\mathrm{rpm})$ & 540 & $9.56 \pm 1.18 \mathrm{ab}$ & $178.02 \pm 2.93 \mathrm{~b}$ & $50.00 \pm 5.00 \mathrm{~b}$ & $0.752 \pm 0.03 \mathrm{ab}$ \\
& 600 & $10.11 \pm 0.43 \mathrm{ab}$ & $140.55 \pm 3.10 \mathrm{c}$ & $95.28 \pm 2.93 \mathrm{a}$ & $0.620 \pm 0.04 \mathrm{~b}$ \\
& 660 & $10.93 \pm 1.95 \mathrm{a}$ & $136.11 \pm 4.48 \mathrm{c}$ & $96.00 \pm 3.61 \mathrm{a}$ & $0.666 \pm 0.09 \mathrm{ab}$ \\
\hline \multirow{5}{*}{ Suhu $\left({ }^{\circ} \mathrm{C}\right)$} & 80 & $8.41 \pm 0.28 \mathrm{~b}$ & $170.62 \pm 7.27 \mathrm{bc}$ & $92.93 \pm 2.30 \mathrm{a}$ & $0.674 \pm 0.05 \mathrm{a}$ \\
& 90 & $9.92 \pm 0.37 \mathrm{a}$ & $165.19 \pm 6.58 \mathrm{c}$ & $94.45 \pm 0.63 \mathrm{ab}$ & $0.626 \pm 0.16 \mathrm{ab}$ \\
& 100 & $9.94 \pm 0.73 \mathrm{a}$ & $166.61 \pm 6.58 \mathrm{c}$ & $95.28 \pm 2.93 \mathrm{ab}$ & $0.603 \pm 0.06 \mathrm{ab}$ \\
& 110 & $9.15 \pm 0.14 \mathrm{ab}$ & $187.20 \pm 12.24 \mathrm{~b}$ & $96.25 \pm 3.75 \mathrm{ab}$ & $0.589 \pm 0.05 \mathrm{ab}$ \\
& 120 & $9.27 \pm 1.24 \mathrm{~b}$ & $213.01 \pm 15.84 \mathrm{a}$ & $98.50 \pm 1.32 \mathrm{~b}$ & $0.497 \pm 0.04 \mathrm{~b}$ \\
\hline
\end{tabular}

\section{Pengujian}

Hasil pengujian besaran daya dan arus listrik selama proses pengoperasian ditampilkan pada Gambar 6. Berdasarkan grafik tersebut nilai rata-rata arus sebesar 6.97 Ampere dan daya 2.31 Kilowatt sedangkan nilai maksimal untuk arus ialah 15.60 Ampere dan daya sebesar 5.17 Kilowatt.

Sedangkan grafik kecepatan putaran screw dan suhu ditunjukkan pada Gambar 7. Putaran screw diatur pada frekuensi $20 \mathrm{~Hz}$ (600 rpm) dan selama proses ekstrusi bahan, putaran screw mengalami fluktuasi yaitu maksimal 599 rpm, minimal 520 rpm dan rata-rata $555.24 \mathrm{rpm}$. Suhu barrel tercatat maksimal $98.74^{\circ} \mathrm{C}$, minimal $93^{\circ} \mathrm{C}$ dan rata-rata $98.74^{\circ} \mathrm{C}$.

\section{Performansi mesin dan kualitas pakan}

Dari hasil pengujian ekstruder dengan beberapa perlakuan diperoleh nilai kapasitas dan SME mesin serta nilai kualitas pakan meliputi unit density dan daya apung. Detail hasil pengujian ditampilkan pada Tabel 2.

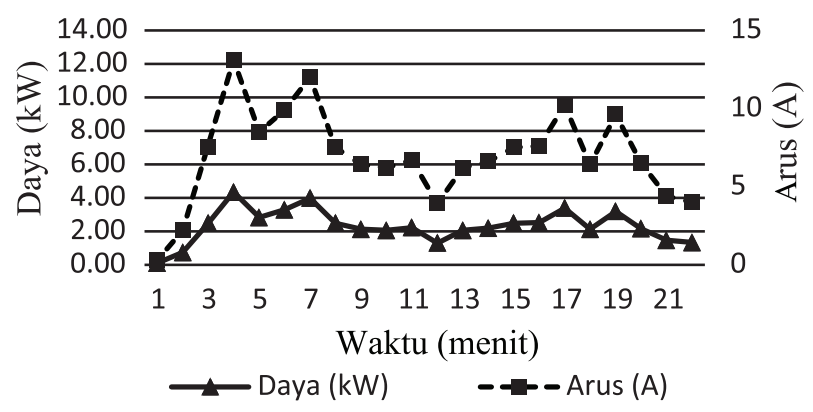

Gambar 6. Nilai arus dan daya ekstruder selama proses,

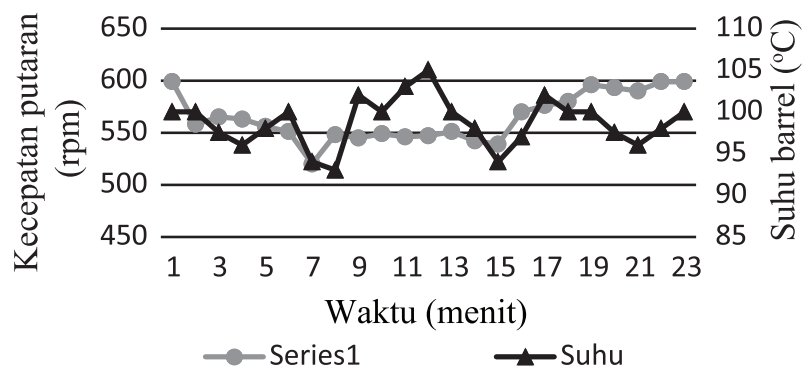

Gambar 7. Kecepatan putaran screw dan suhu barrel selama proses.

\section{Kapasitas}

Kapasitas ekstruder hasil perancangan dalam memproduksi pakan adalah sebesar 7.35 - 10.93 $\mathrm{kg} / \mathrm{jam}$. Perubahan kecepatan putaran screw menghasilkan nilai kapasitas ekstruder yang berbeda. Semakin cepat atau tinggi putaran screwakan diperoleh nilai kapasitas yang semakin besar pula. Screw yang berputar lebih cepat akan mendorong bahan menuju dies lebih cepat dan akan terjadi sebaliknya. Menurut Wei et al (2013), kecepatan putaran screw sangat mempengaruhi laju aliran bahan selain juga akan berpengaruh pada tingkat homogenitas bahan. Putaran screw yang lebih tinggi akan menghasilkan laju aliran bahan yang semakin besar.

Pada perlakuan suhu barrel yang berbeda, kapasitas tertinggi dihasilkan pada suhu barrel $100^{\circ} \mathrm{C}$ yaitu $9.94 \mathrm{Kg} / \mathrm{jam}$. Pola kapasitas yang dihasilkan ialah pada suhu $80^{\circ} \mathrm{C}$ kapasitasnya hanya sebesar $8.41 \mathrm{Kg} /$ jam, kemudian kapasitas naik hingga pada suhu $100^{\circ} \mathrm{C}$ dan mulai turun kembali pada suhu 110 dan $120^{\circ} \mathrm{C}$. Dalam suhu barrel dibawah $90^{\circ} \mathrm{C}$ bahan pakan yang diolah belum mengalami proses gelatinisasi sempurna. Bahan yang mengalami gelatinisasi sempurna akan bersifat licin karena amilosa dalam pati meleleh dan membentuk larutan/cairan kental sebelum menjadi gel. Cairan inilah yang menyebabkan bahan mudah terdorong ke dies. Namun bila panas semakin tinggi $\left(110^{\circ} \mathrm{C}\right)$ sebagian bahan akan mengalami matang berlebih dan mengeras sehingga gesekan bahan dengan barrel menjadi besar akibatnya bahan akan lambat terdorong menuju dies. Hal ini didukung oleh hasil penelitian $\mathrm{Ji}$ et al (2017) tentang pengaruh tekanan dan suhu terhadap derajat gelatinisasi senyawa pati. Disebutkan bahwa molekul pati pada proses gelatinisasi mulai meleleh pada suhu $80^{\circ} \mathrm{C}$ kemudian berlanjut hingga suhu $100^{\circ} \mathrm{C}$ setelah itu cairan kental dari pati tersebut akan semakin mengeras karena suhu yang semakin tinggi akan menyebabkan air bebas dalam larutan/cairan menguap.

\section{SME}

Berdasarkan data pada Tabel 2. Nilai SME ekstruder cenderung turun dengan meningkatnya kecepatan putar screw. Menurut Zhang et al (2015) SME ektruder dipengaruhi oleh konfigurasi screw, putaran screw, torsi motor dan laju aliran bahan / kapasitas. 
Dalam penelitian ini putaran screw tidak memberikan pengaruh besar dibandingkan dengan perubahan kapasitas, sehingga putaran screw yang tinggi dengan nilai kapasitas yang tinggi akan menurunkan nilai SME. Hal ini juga disebabkan akibat nilai torsi yang kecil ketika putaran screw tinggi sehingga nilai SME menjadi kecil (Gambar 8).

Perbedaan suhu barrel mempengaruhi nilai SME mesin ekstruder. Pada perlakuan suhu 80, 90 dan $100^{\circ} \mathrm{C}$, nilai SME-nya tidak berbeda nyata dengan nilai 170.62 - $166.61 \mathrm{KJ} \mathrm{Kg}^{-1}$. Kemudian SME naik pada perlakuan suhu 110 dan $120^{\circ} \mathrm{C}$ dengan nilai sebesar

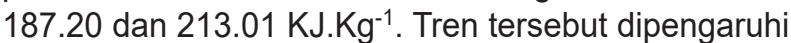
oleh perubahan suhu barrel yang berimbas pada kapasitas lalu menyebabkan perubahan nilai SME. Suhu yang terlalu tinggi mengakibatkan kapasitas rendah sehingga SME naik.

\section{Daya apung}

Parameter utama kualitas pakan yang diamati dalam penelitian ini adalah daya apung. Dalam proses ekstrusi bahan mengalami pemanasan, pengadukan dan tekanan yang tinggi sehingga pada saat keluar dari dies bahan akan mengembang akibat adanya perubahan tekanan dan suhu yang tiba-tiba. Uap air diantara matrik penyusun pakan akan menguap dan membentuk pori-pori dalam matrik sel yang ditinggalkan (Ayadi et al, 2011). Pori-pori inilah yang menyebabkan pakan bisa mengapung dalam air. Berdasarkan data pada Tabel 2. Perlakuan perbedaan kecepatan putaran screw berpengaruh nyata pada daya apung. Daya apung tertinggi pada perlakuan putaran $660 \mathrm{rpm}(96.00 \pm 3.61 \%)$ dan tidak berbeda nyata dengan perlakuan $600 \mathrm{rpm}$ (95.28 $\pm 2.93 \%$ ). Hal ini disebabkan karena pada putaran yang tinggi menghasilkan tekanan yang lebih tinggi (Emin et al, 2016). Tekanan tersebut menyebabkan bahan bisa mengembang maksimal saat melewati dies. Putaran screw yang tinggi menyebabkan tekanan dalam screw meningkat yang menyebabkan bahan akan mengembang dan membetuk pori saat keluar dies (Wei et al, 2013).

Peningkatan suhu dalam ekstruder menyebabkan peningkatan daya apung. Daya apung terendah pada perlakuan suhu $80^{\circ} \mathrm{C}$ yaitu $92.93 \pm 2.30$ (\%) sedangkan tertinggi pada perlakuan suhu $120^{\circ} \mathrm{C}$ yaitu $98.50 \pm 1.32$ (\%). Menurut Kamarudin et al (2018),

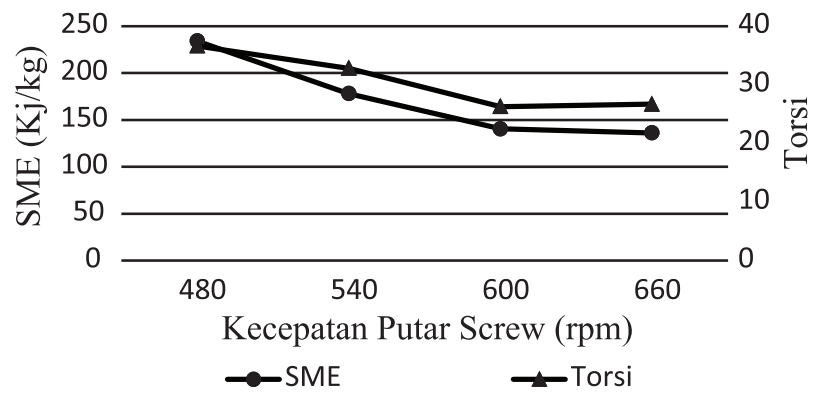

Gambar 8. Hubungan kecepatan putar screw, torsi dan SME. pakan ikan terapung karena terbentuknya porositas akibat tekanan dan suhu yang tinggi saat proses dan ukuran pori akan semakin besar jika suhu dinaikkan.

\section{Unit density}

Unit density pakan yang dihasilkan ialah $0.620 \pm$ $0.04-0.782 \pm 0.03\left(\mathrm{~g} / \mathrm{cm}^{3}\right)$. Pada kecepatan screw yang lebih tinggi akan menghasilkan unit density pakan yang lebih rendah. Putaran screw yang cepat menghasilkan pakan dengan pori lebih besar karena bahan mampu mengembang lebih besar. Hal ini akibat tekanan yang lebih kuat dibandingkan tekanan pada putaran screw yang rendah dalam proses ekstrusi. Hasilnya berat jenis pakan yang didapatkan menjadi lebih kecil. Hasil serupa juga disampaikan oleh Rosentrater et al (2009) bahwa peningkatan kecepatan screw akan menurunkan unit density.

Kenaikan suhu pada ujung screw menyebabkan penurunan unit density pakan. Unit density terendah pada perlakuan suhu $120^{\circ} \mathrm{C}$ yaitu $0.497 \pm 0.04\left(\mathrm{~g} / \mathrm{cm}^{3}\right)$ dan berbeda signifikan dengan unit density terendah pada perlakuan suhu $80^{\circ} \mathrm{C}$ yaitu $0.674 \pm 0.05(\mathrm{~g} /$ $\mathrm{cm}^{3}$ ). De cruz et al (2015) mengemukakan bahwa peningkatan suhu dari $125-175^{\circ} \mathrm{C}$ pada ujung screw ekstruder menyebabkan penurunan density pakan ikan. Demikian juga disebutkan oleh Gonzales et al (2013) bahwa peningkatan suhu hingga $182.8^{\circ} \mathrm{C}$ akan meningkatkan derajat pemasakan yang memhasilkan produk dengan density rendah.

\section{Simpulan}

Berdasarkan hasil penelitian dapat diambil kesimpulan sebagai berikut :

1. Pakan ikan terapung bisa diproduksi menggunakan mesin ekstruder twin screw. Dengan komponen utama terdiri dari motor penggerak, twin screw, barrel, elemen pemanas, dies dan pemotong.

2. Dalam produksi pakan, kebutuhan daya maksimal sebesar $5.17 \mathrm{~kW}$, kecepatan putar screw optimal $600 \mathrm{rpm}$, suhu barrel optimal $100^{\circ} \mathrm{C}$, kapasitas terendah $7.35 \mathrm{~kg} / \mathrm{jam}$ dan tertinggi $10.93 \mathrm{~kg} / \mathrm{jam}$,

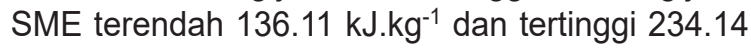
kJ.kg-1.

3. Pakan ikan yang dihasilkan memiliki daya apung terendah $30.00 \%$ dan tertinggi $98.50 \%$, unit density $0.497-0.782 \mathrm{~g} / \mathrm{cm}^{3}$.

\section{Daftar Pustaka}

Adekola, K.A. 2016. Engineering Review Food Extrusion Technology and Its Applications. Journal of Food Science and Engineering. Vol 6:149-168.

Ayadi, F.Y., K.A. Rosentrater., K. Muthukumarappan., M.L. Brown. 2011. Twin-screw extrusion processing of distillers dried grains with solubles (DDGS)based Yellow Perch (Perca flavescens) Feeds. Food Bioprocess Technol. Vol 5: 1963-1978. 
Budijanto, S., A.B. Sitanggang., H. Wiaranti., B. Koesbiantoro. 2012. Pengembangan Teknologi Sereal Sarapan Bekatul dengan Menggunakan Twin Screw Extruder. J. Pascapanen. Vol 9(2): 63 -69 .

De Cruz, C.R., M.S. Kamarudin., C.R. Saad., E.R. Fard. 2015. Effects of extruder die temperature on the physical properties of extruded fish pellets containing taro and broken rice starch. Anim. Feed Sci. Technol. Vol 199: 137-145.

Draganovica, V., A.J. Goot., R. Boom., J. Jonkers. 2011. Assessment of the effects of fish meal, wheat gluten, soy protein concentrate and feed moisture on extruder system parameters and the technical quality of fish feed. Animal Feed Science and Technology. Vol 165: 238-250.

DJPB (Direktorat Jenderal Perikanan Budidaya). 2015. Gerpari untuk Indonesia Mandiri. Buletin Akuakultur Indonesia. № 13 (2).

Emin, M.A., T. Teumer., W. Schmitt., M. Radle., H.P. Schuchmann. 2016. Measurement of the true melt temperature in a twin-screw extrusión processing of starch based matrices via infrared sensor. Journal of Food Engineering. Vol 170: 119-124.

Evon, P.H., V. Vandenbossche., P.Y. Pontalier., L. Rigal. 2009. Aqueous extraction of residual oil from sunflower press cake using a twin-screw extruder: Feasibility study. Industrial Crops and Products. Vol 29: 455-465.

Gonzales, R.J., E.P. Cavada., V.J. Pena., R.L. Torres., M.D. De Greef., S.R. Drago. 2013. Extrusion conditions and amylose content affect physicochemical properties of extrudates obtained from brown rice grain. International Journal Food Science. Vol 58:41-48.

Gunadi, B., R. Febrianti., Lamanto. 2010. Keragaan Kecernaan Pakan Tenggelam dan Terapung untuk Ikan Lele Dumbo (Clarias gariepinus) dengan dan Tanpa Aerasi. Prosiding Forum Inovasi Teknologi Akuakulture.

Harold, F.G. Jr., Jr. R.W. John., M. M. Eldridge. 2005. Extrusion: The Definitive Processing Guide and Handbook. William Andrew Publishing. Norwich. New York. USA

Harper, J.M. 1979. Food extrusion. CRC Crit. Rev. Food Sci. Nutr. 11, 155-215.

Ji, Z., L.Yu., H. Liu., X. Bao., Y. Wang., L. Chen. 2017. Effect of pressure with shear stress on gelatinization of starches with different amylose/amylopectin ratios. Food Hydrocolloids. Vol 72: 331-337
Kamarudin, M.S., C.R. de Cruz., C.R. Saad, N. Romano., E.R. Fard. 2018. Effects of extruder die head temperature and pre-gelatinized taro and broken rice flour level on physical properties of floating fish pellets. Animal Feed Science and Technology, 236: 122-130

Kurniawan, A., R.A. Lestariadi. 2017. Induction Of Fish Pellet Making Machine To Improve Feed Community Program In Catfish Farmers In Mojokerto Regency. Journal of Innovation and Applied Technology. Vol 3 (01): 433-438.

Philipp, C., I. Oey., P. Silcock., S.M. Beck., R. Buckow. 2017. Impact of protein content on physical and microstructural properties of extruded rice starchpea protein snacks. Journal of Food Engineering. Vol 212: 165-173.

Purwasasmita, B.S dan P. H. Roland. 2008. Sintesa, karakterisasi dan fabrikasi material berpori untuk aplikasi pelet apung (Floating Feed). Jurnal Bionatura. Vol 10 (1): 13-28.

Rosentrater, K.A., K. Muthukumarappan, S. Kannadhason. 2009. Effects of ingredients and extrusion parameters on aquafeeds containing DDGS and potato starch. Journal of Aquaculture Feed Science and Nutrition. Vol 1(1): 22-38.

Samuelsen, T.A., A. Oterhals., K. Kousoulaki. 2018. High lipid microalgae (Schizochytrium sp.) inclusion as a sustainable source of $n-3$ long-chain PUFA in fish feed-Effects on the extrusion process and physical pellet quality. Animal Feed Science and Technology. Vol 236: 14-28.

Senanayake, S.A.M.A.N.S., Clarke, B. 1999. A simplified twin screw co-rotating food extruder: design, fabrication and testing. Journal of Food Engineering. Vol 40: 129-137.

Wei, J., Q. Sun., X. Sun., W. Sun. 2013. AStudy on Rotor Profiles Design for a Novel Twin screw Kneader. International Journal Of Precision Engineering And Manufacturing. Vol 14(3): 451-459.

Yaqoob, M., M.R. Ali., S. Mehmood. 2010. Comparison of Growth Performance of Major and Chinese Carps Fed on Floating and Sinking Pelleted Supplementary Feeds in Ponds. Pakistan Journal Zoologi. Vol 42(6): 765-769.

Zhang, B., Y. Zhang., J. Dreisoerner., Y. Wei. 2015. The effects of screw configuration on the screw fill degree and special mechanical energy in twinscrew extruder for high-moisture texturised defatted soybean meal. Journal of Food Engineering. Vol 157: 77-83. 